DEUIFD XLIV / 2016, ss. 181-210.

\title{
HANEFÎLERDE ÂMMIN KAPSAMI VE ARKA PLANINDAKİ TARTIŞMALAR
}

Ömer YILMAZ*

\author{
ÖZ
}

Âm lafızların kapsamına ilişkin olarak Hanefî âlimlerin görüşleri incelendiğinde konunun nahivle ve kelâmla yoğun ilişki içinde olduğu görülmektedir. Bazı Hanefî âlimlerin kelâmî bir tartışma olarak büyük günah işleyenlerin durumunu âm lafizların kapsamı çerçevesinde ele almaları, konunun kelâmî yönünü göstermektedir. Zira Ehl-i sünnete göre büyük günah işleyen müslümanlar, cehennemde ebedi olarak kalmayacaklardır. Bu hükme ulaşılabilmesi ise şirk dışındaki günahların affedileceğini belirten âyetlerin genel kapsamlı olduklarının kabulüne bağlıdır. Diğer yandan âmmın kapsamına ilişkin görüş ayrılıklarının temelinde nahivle ilgili tartısmaların yer alması, konunun esas itibariyle bir nahiv meselesi olduğunu da göstermektedir. Ancak konunun kelâmî yönü, nahivle olan ilişkisinden daha fazla gündeme taşınmıştır. Çünkü Hanefiler ve Mu’tezile, âm lafizların genel bir kapsama sahip oldukları noktasında görüş birliğine varmışlardır. Bu görüş birliğini kimi araştırmacılar, özellikle Irak Hanefîlerinde Mu’tezilî etkinin varlığına delil olarak göstermişlerdir. Ancak Hanefîler, büyük günah işleyenlerin imandan çıkmadıklarını ve cehennemde ebedi olarak kalmayacaklarını kabul etmişlerdir. Bu konuda Mu’tezile karşıtı bir görüss benimseyen Hanefîlerin, âmmın genel bir kapsama sahip olduğu noktasında onlarla görüş birliğine varmış olmaları; âmmın nahiv ve lügat ilimleriyle ilişkisi göz önünde bulundurulduğunda anlaşllır hale gelmektedir.

Anahtar Kelimeler: Âm, Tevakkuf, Mürtekib-i kebire.

\section{THE SCOPE OF THE GENERAL TERM IN HANAFI TRADITION AND DISCUSSIONS IN THE BACKGROUND}

\section{ABSTRACT}

When Hanefi ideas on the scope of the general term in Hanafi tradition and discussions in the background are examined, it can be seen that the subject is deeply concerned with syntax and theology. A number of Hanafi scholars handle Muslims who have committed a grave sin in the scope of the general

* Yrd. Doç. Dr., Namık Kemal Üniversitesi, İlahiyat Fakültesi, İslam Hukuku ABD, omeryilmaz@nku.edu.tr

Makalenin Hakemlere Gönderiliş Tarihi : 24/03/2016

Makalenin Hakemlerden Geliş Tarihi : 06/06/2016 
term. According to Ahl al-sunnah, those who have committed a grave sin will not stay in hell forever. Thus, verses related with forgiveness of Allah need to be evaluated in a general scope. On the other hand, the issue is in fact a subject matter of syntax. Regarding this, Hanafis and Mutazilis have a consensus over this. Some discuss that Iraqi Hanafis was strongly influenced by Mutazilism. But Hanafis and Mutazilis disagree on the last judgment about those who have committed a grave sin. Clarifying this depends on examining syntax aspect of the issue.

Keywords: The General Term, Skepticism, Grave Sinner.

\section{Giriş}

Âm lafżn kapsamı ve Hanefî usûlündeki gelişimi, kelâm ilmiyle yoğun bir ilişki içerisindedir. Buna dayalı olarak bazı âlimler kelâmî bir tartışma olarak "büyük günah işleyenlerin durumu"nu âm lafzın kapsamı çerçevesinde ele almıșlardır. ${ }^{1}$ Bunun en önemli örneğini Cessâs’ta (ö. 370/981) görmekteyiz. O, konunun kelâmî yönünü ziyadesiyle vurgulamış ve büyük günah işleyenlerin durumunu âm lafzın kapsamıyla ilgili tartısmalara örnek vermiştir. ${ }^{2}$ İki konu arasındaki bağlantı, kısaca şöyle ortaya konabilir: Ehl-i sünnete mensup kelâm âlimlerine göre büyük günah işleyen müslümanlar, Cehennem'de ebedi olarak kalmayacaklardır. ${ }^{3}$ $\mathrm{Bu}$ hükme ise ancak şirk dışındaki günahların affedileceğini belirten âyetlerin ${ }^{4}$ genel kapsamlı olduklarının kabulü ile ulaşılabilir.

Ayrıca bir başka husus da Hanefî âlimlerin âmmın kapsamına ilişkin olarak bunun "dil ilimleriyle ilgili bir mesele" olduğunu vurgulamış olmalarıdır. ${ }^{5}$ Ancak konunun bu yönü üzerinde daha fazla durulması

\footnotetext{
1 Büyük günahın ne olduğu hususunda çeşitli itikādî fırkalar tarafından pek çok farklı görüş ileri sürülmüştür. Ancak bunların bazı ortak noktalarda birleştiği görülmektedir. Buna göre kat'î delille sabit olan ve hakkında ceza ön görülen davranışlar, "büyük günah" olarak nitelenebilir. bk. Eş'arî, Makālâtuïl-İslâmiyyîn (thk. Muhammed Muhyiddîn Abdülhamîd), Beyrut 1990, I, 150-152.

2 Cessâs, el-Fusûl fi'l-usûl (nşr. Uceyl Câsim en-Neşemî), Küveyt 1405/1985, I, 103.

3 Mâtürîdî, Kitâbü’t-Tevhîd (trc. Bekir Topaloğlu), Ankara 2005, s. 429-430; Adil Bebek, "Kebîre", DIA, XXV, 163-164.

4 en-Nisâ 4/48, 116; ez-Zümer 39/53; Muhammed 47/4; Yûsuf 12/87; Leyl 92/15.

5 Bununla ilgili örnekler için bk. Cessâs, el-Fusûl, I, 104-105; Lâmişî, el-Kitâb fì Usûli’fikeh (thk. Abdülmecîd Türkî), Beyrut 1415/1995, s. 122-124; Alâeddin Semerkandî, Mî̃ânül-usûl fì netâici'l-ukèll (nşr. M. Zekî Abdülber), Devha 1404/1984, I, 365-366.
} 
gerekmektedir. Zira Hanefîler ve Mu'tezile, âmmin genel bir kapsama sahip olduğu noktasında görüş birliğine varmışlardır. ${ }^{6}$ Âmmın kapsamına ilişkin olarak Hanefîlerdeki baskın görüşle Mu’tezile arasındaki bu görüş birliğinin anlaşılması, konunun dil ilimleriyle ilişkisinin açıklığa kavuşmasına bağlıdır. Söz konusu görüş birliğini kimi araştırmacılar, özellikle Irak Hanefîlerinde Mu'tezilî etkinin varlığına delil olarak göstermişlerdir. ${ }^{7}$ Ancak Hanefỉlere göre büyük günah işleyenler, imandan çıkmadıkları gibi Cehennem'de de ebedi olarak kalmayacaklardır. Bu durumda büyük günah işleyenlerin akıbetine ilişkin olarak Mu'tezile karşıtı bir görüş benimseyen Hanefîlerin âmmın kapsamı konusunda onlarla görüş birliğine varmış olmaları izaha ihtiyaç duymaktadır. Araştırma, söz konusu duruma açıklık kazandırma amacı gütmektedir.

Yazı, üç bölümden oluşmaktadır. Birinci bölümde âmmın kavramsal çerçevesi ve kapsamı Hanefî usûlü çerçevesinde incelenecektir. İkinci bölümde büyük günah işleyenin durumuyla ilgili kelâmî tartısmanın âmmın kapsamıyla ilişkisi üzerinde durulacaktır. Üçüncü bölümde ise özellikle nahiv ve lügat ilimlerinde âm lafizla ilgili meseleler ele alınacaktır.

\section{Hanefî̀ Usûlünde Âm}

Hanefî usûl müelliflerinin âm lafza getirdikleri tanımlar, âmmın kapsamı konusundaki yaklaşımlarıyla doğrudan irtibatlıdır. Bu durum, aşağıda açık bir şekilde ortaya konulmaktadır.

\section{A. Hanefî Usûlünde Âmmın Kavramsal Çerçevesi}

Âm, "âmme" fiilinin ismi fâilidir. Âmme, "kapsamak, içine almak, yayılmak" gibi anlamlara gelir. Âmmın zıddı, "hâs"dır. Bu kelimenin masdar1 ise "umum" şeklinde gelmektedir.

\footnotetext{
Örnekler için bk. Cessas, el-Fusûl, I, 101; Ebü'l-Hüseyin el-Basrî, el-Mu'temed (nşr. Muhammed Hamîdullah), Dımaşk 1384-85/1964-65, I, 203.

7 Aron Zysow, "Mu'tazilism and Maturidism in Hanafi Legal Theory", Studies in Islamic Law and Society (ed. Bernard Weiss), Leiden 2002, s. 235. Bu iddiayı ilk olarak dile getirenlerden birisi Madelung'dur. bk. Madelung, Matüridiliğin Yaynlması ve Türkler (trc. Arslan Gündüz), Leiden 1971, s. 4.

8 İbn Manzûr, Lisânü'l-'Arab, Beyrut 1414/1994, “amm” md.
} 
Cessâs, fikıh usûlüne dair eseri el-Fusûl fi'l-usû̉ de âmma yönelik bir tanım getirmemiştir.' Ancak el-FusûPden sonraki Hanefî usûl eserlerinin pek çoğunda ona nisbet edilen âm tanımı şöyledir: "Âm, isimleri ya da mânaları toplu olarak içeren lafızdır." " $\mathrm{Bu}$ tanım, Cessâs'tan sonraki Hanefî âlimlerinden birçoğu tarafindan eleștirilmiştir. Debûsî’nin (ö. 430/1039) getirdiği eleștiri, "bir lafzın birden fazla mânayı tek bir kullanımda ifade etmesinin mümkün olmadığı" șeklinde olmuştur. ${ }^{11}$ Buna benzer bir eleştiriyi Serahsî (ö. 483/1090) de yöneltmiştir: "Mânaların taaddüdü, ancak tegayür ve ihtilaftan sonra mümkün olabilir." ${ }^{12}$ Buna göre lafżn birden fazla mânayı aynı anda içermesi mümkün değildir. Bu, ancak lafzın birden fazla anlamla ve farklı yerlerde kullanılmasıyla mümkün olabilir.

Serahsî, Cessâs'ın tanımına yönelik eleştiride olduğu gibi âmmı tanımlarken de Debûsî̀yi takip eder. Bu âlimlerin benimsediği tanım şöyledir: "Âm, lafız ve mâna itibariyle isimleri toplu olarak içeren lafızdır." "13 $\mathrm{Bu}$ tanımda geçen isimden maksat, isimle ifade edilen varlıklardır. Yine tanımda geçen "lafız ve mâna olarak" ifadesi ise âm lafzın içerdiği fertleri nasıl kapsadığını açıklamak için serdedilmiştir. Bu çerçevede âm lafiz, içerdiği fertleri bazen lafzî olarak bazen de manevi olarak kapsar. "Zeydler" vb. çoğul sîga kullanıldığında lafzî olarak; ismi mevsuller kullanıldığında ise manevi olarak kapsamış olmaktadır. "Umum" sözlükte "şümul" anlamına gelmektedir. İsimleri toplu olarak kapsayan lafizlara "âm" denilmesi de bundan ileri gelmektedir. "Şey" kelimesi ile "âm" arasındaki benzerlik de bundan kaynaklanmaktadır. Çünkü "şey" kelimesi de mevcudatın tamamını kapsamaktadır. ${ }^{14}$

\footnotetext{
9 Cessâs, el-Fusûl, I, 99-112. Bu tespiti Ferhat Koca da teyit etmektedir. bk. Ferhat Koca, İslam Hukuk Metodolojisinde Tahsis (Daraltıcı Yorum), İstanbul 2011, s. 62.

10 Debûsî, Takvîmü'l-edille (thk. Halil Meys), Beyrut 1421/2001, s. 98; Serahsî, Usûlü'sSerahsî (thk. Ebü'l-Vefâ el-Efgânî), Kahire 1954, I, 125.

11 Debûsî, Takvîm, s. 98.

12 Serahsî, Usûl, I, 125.

13 Debûsî, Takvîm, s. 98;Serahsî, Usûl, I, 124-125.

14 Serahsî, Usûl, I, 124-125.
} 
Ebü'l-Yüsr Pezdevî (ö. 493/1100) de âmm1 -Serahsî̀ye benzer şekilde- "isimle ifade edilen mânaları toplu olarak kapsayan lafiz" şeklinde tanımlamışı1 ${ }^{15}$

Alâeddin Semerkandî̀ye (ö. 539/1144) göre ise dil bakımından hangi mânaları ifade etmek üzere konulduysa bu mânalar içerisine giren fertleri eşit bir şekilde kapsayan lafza âm denilir. "İnsan" lafzı bu tanıma girmemektedir. Çünkü bu kelime, fertleri ve uzuvları kapsamaktadır. Ancak bu fertlerden her birisi, insan lafzının ifade etmek üzere konulduğu mânayı kabul etmemektedir. Müşterek lafizlar da bu tanımın dışında bırakılmışlardır. Çünkü bu lafızlar birçok mânaya gelebilmektedir. “Ayn” kelimesi buna örnek teşkil etmektedir. Oysaki tanımda lafız, hangi anlamı ifade etmek üzere konulduysa o mâna içerisine giren fertlerin eşit bir şekilde kapsanması istenmektedir. ${ }^{16}$

Lâmişî ise âmmı şöyle tanımlamıştır: "Âm, dil itibariyle hangi mânayı ifade etmek üzere ortaya konulmuşsa o mâna altına giren fertleri (sınırlı olarak) kapsayan lafızdır." Bu tanıma göre bir lafzın âm olarak nitelenmesi için birden fazla ferdi kapsaması yeterli olmaktadır. Buradan anlaşılan o ki; Lâmişî, bir lafżn âm olarak nitelenmesi için, ifade etmek üzere konulmuş olduğu manaları eksiksiz bir şekilde kapsamasını (istiğrak) şart koşmamaktadır. Oysa ona göre Iraklı Hanefîler; bunu, bir lafzın âm olarak nitelenmesi için şart olarak değerlendirirler. Bu durumda onların âm tanımı şöyle olmalıdır: "Âm, dil itibariyle hangi mânayı ifade etmek üzere ortaya konulmuşsa o mâna altına giren fertleri -hiçbirisi dışarıda kalmamak üzere- kapsayan lafizdır." ${ }^{17}$

Üsmendî (ö. 552/1157 [?]) de bir lafżn âm olarak nitelenmesi için, ifade etmek üzere konulmuş olduğu mânaları eksiksiz bir şekilde kapsamasını (istiğrak) şart koşmaktadır. Ona göre bu husus dikkate alınmadan yapılan tanımlar, yanlıştır. Onun benimsediği tanıma göre "Âm, hangi fertleri kapsamak üzere konulmuşsa bu fertlerin tamamını kapsayan lafizdır." Mesela "er-rical” böyle bir lafizdır. O, kapsamına giren fertlerin tümünü içerir. Tesniye ve cemî lafızlar, bu tanımda

15 Ebü'l-Yüsr Pezdevî, Ma'rifetü'l-buceci'ş-ser'iyye, Kahire 2003, s. 69.

16 Semerkandî, Mî̃ân, I, 360. Müşterek, her biri ayrı vaz ile olmak üzere birden fazla mânaya gelen lafizdır. bk. Ferhat Koca, "Müşterek”, DİA, XXXII, 172-174.

17 Lâmişî, el-Kitâb, s. 116. 
dışarıda bırakılmış olmaktadır. Çünkü tesniye lafızlar, iki ferdi kapsar, çoğulu kapsamaz. Aynı şekilde "on" kelimesi de onlu mânaları ifade etmede kullanılmakla birlikte onlu mânaların tamamını kapsamamaktadır. Tanımda geçen "hangi fertleri kapsamak üzere konulmuşsa" ifadesiyle kastedilen, hakikat ve mecaz anlamlardır. Böylelikle âm lafzın, hem hakikat hem de mecaz anlamları aynı anda kapsamasının gerekmediği ifade edilmiş olmaktadır. Bu durumda bir lafız, hakikat anlamıyla kapsaması gereken fertlerin tamamını kapsamışsa âm kabul edilir. Aynı şekilde mecaz anlamıyla kapsaması gereken fertlerin tamamını kapsamışsa da yine âm kabul edilir. Böylece âm ile ilgili ortaya konulan bu tanımın diğer tanımlardaki kusurlardan uzak olduğu söylenebilir. ${ }^{18}$

Habbâzî̀nin (ö. 691/1292) âm tanımı da Serahsî̀nin ve EbülYüsr Pezdevî̀nin tanımıla aynı çizgidedir. O da âmmı, "varlıkları toplu olarak (cem' ederek) kapsayan lafız" şeklinde tanımlamıştır. ${ }^{19}$

Nesefî (ö. 710/1310) ise âmm1, "içerdiği fertleri şümul yoluyla ihtiva eden lafız" şeklinde tanımlamıştır. Bu tanımda müşterek, kayıt dışında bırakılmıştır. Zira müşterek, aynı tanım altına girmeyen isimleri de kapsamına almaktadır. ${ }^{20}$

Âmma getirilen tanımda müştereki kapsam dışında bırakmaya yönelik dikkat, Sadrüşşerîa'da (ö. 747/1346) ve Teftâzânî’de (ö. 792/1390) de görülür. Her iki âlime göre de âm, tek bir kullanımda sınırsız olarak çokluk belirten ve kapsamı altına giren fertleri istisnasız olarak içeren (müstağrik) lafızdır. ${ }^{21} \mathrm{Bu}$ tanıma dikkat edildiğinde kapsam dışında bırakılanın, sadece müşterek olmadığı anlaşılmaktadır. Ayrıca sayı isimleri, sınırlı sayıda ferdi içerdikleri için tanım dışında bırakılmıştır. Yine çokluk belirtmedikleri için şahıs isimleri de kapsam dışında kalmışlardır. Âmmın, "kapsamı altına giren fertleri istisnasız olarak içermesi" de

18 Üsmendî, Bęlünn-nazar fîl-usul (thk. Muhammed Zekî Abdülber), Kahire 1992/1412, s. 160.

19 Habbâzî, el-Muğnî fì usûli'l-fikeh (thk. Muhammed Mazhar Beka), Mekke 1983, s. 99.

20 Nesefî, Keşü'l-esrâr, Beyrut 1986/1406, I, 161-163.

21 Sadrüşşerîa, et-Tav₹îh, s. 45; Teftâzânî, et-Telvîh (nşr. Zekeriyyâ Umeyrat), Beyrut ts. , I, 55 . 
tanımın önemli bir kaydıdır. Nekre halinde kullanılan cemîlerin "âm” olarak değerlendirilmemesi, bundan ileri gelmektedir. ${ }^{22}$

İbnü'l-Hümâm'a (ö. 861/1457) göre ise âm, kapsamındaki fertleri istisnasız bir şekilde içeren (istiğrak) lafızdır. ${ }^{23} \mathrm{Bu}$ tanıma göre bir lafzın âm olarak nitelenmesi için kapsamı altındaki fertleri istisnasız bir şekilde içermesi gerekmektedir. Âmmın tanımına ilişkin olarak Molla Hüsrev (ö. 885/1480) de benzer bir yaklaşım içerisindedir. Ona göre de âm, herhangi bir sınırlama olmaksızın kapsamı altındaki fertlerin tamamını içeren lafizdır. ${ }^{24}$

Netice itibariyle Hanefî usûl eserleri çerçevesinde yapılan bu kronolojik incelemeye ayn geleneğe bağlı olarak ilerleyen dönemlerde kaleme alınmış başka eserlerin ilave edilmesi de mümkündür. Ancak bu konuda incelemenin genişletilmesi, eldeki verilere kayda değer bir ilavede bulunmadığ 1 için incelenen eserlerle iktifa edilebilir. Şimdiye kadar ele alınan tanımlar, Hanefî usûlünde âmmın kapsamı açısından istiğrak/istîâb ve şümul olarak nitelenebilecek iki eğilimin varlığını göstermektedir. Zira umum, "istiğrak/istiâb" anlamına geldiği gibi "kesret, ictimâ ve şümul" anlamlarına da gelmektedir. ${ }^{25}$ Umumun "istiğrak/istîab" anlamına geldiğini düşünenlere göre âm, kapsamı altındaki fertleri eksiksiz olarak içermektedir. Umumun kesret, ictimâ ve şümul anlamına geldiğini ileri sürenlere göre ise bir lafzın âm olarak nitelenmesi için birden fazla ferdi kapsamas1 yeterlidir; kapsamı altındaki fertleri eksiksiz olarak içermesi gerekmemektedir. Buna dayalı olarak Lâmişî, Hanefîler arasında coğrafi bir ekolleşmenin varlığına işarette bulunur. Ona göre Iraklı Hanefîlerin çoğunluğu; istiğrakı/istiâb1, âmmın şartı olarak görmüşlerdir. Orta Asya Hanefîlerine göre ise âmmın şartı; şümuldür. ${ }^{26}$ Debûsî ve onun takipçileri olarak Serahsî ve Fahrülislâm Pezdevî'nin âmma yaklaşımları

\footnotetext{
Sadrüşşerîa, et-Tavzîh, s. 45.

23 İbnü'l-Hümâm, et-Tahrîr fî̀ ilmi'l-usûl, Misır 1932, s. 62; Emîr Pâdişâh, Teysîru't-tahrîr, Misir 1931, I, 190-191.

24 Molla Hüsrev, Mirkātü'l-vüsûl ilâ ilmi'l-usûl (trc. Haydar Sadıkoğlu), İstanbul 2012, s. 143.

25 Lâmişî, el-Kitâb, s. 115.

26 Bu konudaki değerlendirmeler için bk. Lâmişî, el-Kitâb, s. 115; Semerkandî, Mîzân, I, 354.
} 
incelendiğinde Lâmişînin Orta Asya Hanefîleri hakkındaki değerlendirmesinin yerinde olduğu anlaşılmaktadır. Ancak Hanefîlerde özellikle geç dönem usûl-i fikıh müellifleri arasında istiğrak1/istîâb1, âmmın şartı olarak gören eğilimin güçlendiği gözden 1rak tutulmamalıdır. ${ }^{27}$

\section{B. Âmmin Kapsam}

Âm lafizların içeriğinin sınırlı olup olmadığı tartışma konusu olmuştur. Bazı âlimlere göre bu lafızların içeriğine lafzın sözlük anlamı itibariyle kapsamı altına giren fertlerin tamamı girmektedir. Bu görüşü savunanlara "ashâbü'l-umum” denilmiştir. Bazı usûl âlimlerine göre ise lafzın içeriğine sözlük anlamı itibariyle giren fertlerin tamamı değil en azı girmektedir. $\mathrm{Bu}$ görüşü savunanlar da "ashâbüll-husus" olarak nitelenmiştir. "Âm lafızların kapsamı bilinemez, o yüzden umum ya da husus şeklinde hüküm vermekten kaçınmak gerekir.” diyenlerse ashâbü’lvakf olarak nitelenmişlerdir. ${ }^{28}$

Ancak şu kadarı var ki; ne Ebû Hanîfe ne de mezhebin kurucu imamlarından diğerleri, âmmın kapsamıyla ilgili açık bir görüş beyan etmiş değildir. Bununla birlikte Cessâs, mezhebin kurucu imamlarının ictihadlarından yola çıkarak onların görüşlerini tesbite çalışmaktadır. Bu arada vardığı sonucu Kerhîye (ö. 340/952) ve Îsâ b. Ebân'a (ö. 221/836) dayandırmak suretiyle mezhebin kurucu imamlarının da bu görüşte olduğuna okuyucusunu ikna etmeye çalışmaktadır. Ona göre mezhebin kurucu imamları, haberlerin ve emirlerin tamaminda âm lafzın genel bir kapsama sahip olduğunu kabul etmişlerdir. $\mathrm{Bu}$, aynı zamanda ehli ilmin cumhurunun da görüşüdür. Zira onlar: "Haberlerin ve emirlerin tamamında lafzın genel bir kapsama sahip olduğu kabul edilerek hüküm verilmelidir. Delil olmadıkça tahsise ya da tevakkufa yönelinmez." diyerek bunu açıkça ortaya koymuşlardır. ${ }^{29}$

27 Ferhat Koca, âmmın tanımından kaynaklanan bu yaklaşım farklılıklarını üç grup içerisinde değerlendirir. bk. Koca, Tabsis, s. 68-73.

28 Lâmişî, el-Kitâb, s. 121-124. Ayrıca tahsisten sonra âm lafżn kapsamındaki sınırlılığın ne olacağı hakkındaki tartışmalar için bk. Ferhaat Koca, "Tahsis", DL்A, XXXIX, 432-434.

29 Cessas, el-Fusûl, I, 101. Cessâs’ın ifadelerindeki siyak-sibak bağlantısı dikkate alındığında burada "mezhep" ile neyi kastettiği açıklık kazanmaktadır. Buna göre 
Gerek Debûsî gerekse onun izinden giden Serahsî ve Fahrülislâm Pezdevî, âmmın genel bir kapsama sahip olduğunu ifade etmişlerdir. Ayrıca onlar, bunu "Hanefîler arasındaki baskın görüş" olarak değerlendirmişlerdir..$^{30}$ Lâmişî, Hanefîlerin ve Mu’tezile'nin çoğunluğuna nisbet edilen bu görüşle ilgili olarak coğrafi bir ekolleşmeye şu şekilde işaret etmiştir: "Kerhî ve Cessâs gibi Irak meşayıhı, Debûsî ve takipçileri gibi diyarımızın müteahhir âlimlerinin çoğunluğu ve bu görüşü tercih eden Mu’tezilî çoğunluk şöyle demektedir: "Âmmın kapsamına giren her bir fertle ilgili olarak hem amel ve hem de itikad gereklidir." 31 Onun "Irak meşayıhı ve diyarımızın müteahhir alimleri” şeklindeki ifadesi, Hanefiler arasında Iraklı Hanefiler ve Orta Asya Hanefileri olarak şekillenen coğrafi ekolleşmenin ilk işaretlerinden sayılabilir. $\mathrm{Bu}$ alıntıda yer verilen "Debûsî̀nin takipçileri" ifadesiyle kastedilen de Serahsî ve Fahrülislâm Pezdevî olmalıdır. ${ }^{32}$ Ayrıca Lâmişî de kendisinden önceki Hanefi usûl âlimleri gibi âmmın genel bir kapsama sahip olduğunu isbata gayret etmiştir. Ona göre dilbilimcilerin ittifakı, sahâbenin çeşitli istidlâlleri ve akıl delili; bunu açıkça ortaya koymaktadır. ${ }^{33}$

Alâeddin Semerkandî̀ye göre de Hanefîler arasındaki baskin görüş, âmmın genel bir kapsama sahip olduğu yönündedir. Ancak o, bu görüşte olanları iki gruba ayırır. Hanefîlerden bazılarına göre âm lafizlar, amelî ve itikādî olarak genel bir kapsama sahiptirler ve kapsamları altındaki fertlerin her biri için nas hükmündedirler. Hanefîlerin çoğunluğu bu görüştedir. Başta Mâtürîdî olmak üzere Semerkand meşayıhına göre ise âm lafız, genel bir kapsama sahip olabildiği gibi hususi bir mânaya işaret ediyor da olabilir. ${ }^{34} \mathrm{Bu}$ demek oluyor ki;

söz konusu kullanımda "mezhep" ile "Hanefîlerin hükme varırken takip ettikleri metotlar” kastedilmiş olmalıdır. Ayrıca bu kullanım, kavramın tarihsel gelişiminin tesbiti açısından da önem taşımaktadır.

30 Debûsî, Takvîm, s. 98; Serahsî, Usûl, I, 135-136; Fahrülislâm Pezdevî, Usûl, bask1 yeri ve tarihi yok, s. 69-73.

31 Lâmişî, el-Kitâb, s. 124.

32 Cessâs-Debûsî-Serahsî-Fahrülislâm Pezdevî çizgisini oluşturan gelenekle ilgili değerlendirmeler için bk. Ferhat Koca, "Usûlü'l-fikh (el-Fusûl fi'l-usûl) Ahmed b. Ali el-Cessâs”, Marife Dini Araştırmalar Dergisi, II/3, Konya 2002, s. 337-340.

33 Lâmișî, el-Kitâb, s. 122-124.

34 Semerkandî, Mî̃ân, I, 385-386. Mâtürîdî, âmmın umum bir kapsama sahip olmasına itiraz etmez. Ancak ona göre âm ile kastedilen, umum olabileceği gibi husus da 
Mâtürîdînnin öncülüğündeki Semerkand âlimleri de âmmın kapsamının genel olabileceğini kabul etmekle birlikte bunu bir zorunluluk olarak görmemektedirler. Burada dikkat çekici olan; başta Mâtürîdî olmak üzere Semerkand âlimlerine ait görüşün, Hanefiler arasındaki baskın görüşle uzlaştırılmasıdır. ${ }^{35}$

Üzerinde durulması gereken bir nokta da âmmin kapsamına ilişkin Mâtüridi'ye ait görüşün, Orta Asya Hanefîleri üzerinde güçlü bir etki bırakmamıș olmasıdır. Nesefî’nin bu konuda da Mâtürîdî ile görüş birliği içerisinde olduğunda tereddüt yoktur. ${ }^{36}$ Ancak bu bölgeye mensup âlimlerden Üsmendî ve Habbâzî gibi bazıları, âmmın kapsamının hususi bir mânaya hasredilmesine karşı çıkarak Mâtürîdî’nin görüşünü reddetmişlerdir. ${ }^{37}$ Buradan anlaşılan o ki; Mâtürîdî̀nin görüşü Orta Asya Hanefîleri arasında da sınırlı sayıda takipçi bulabilmiştir. ${ }^{38}$

\section{D. Âmmın Hükmünde Kat'̂̂lik ve Zannîlik}

Âmmın genel bir kapsama sahip olmasıyla âmma dayalı olarak verilen hükümdeki kat’̂lik arasında doğrudan bir ilişki vardır. Bu çerçevede Hanefîler arasında âmmın genel bir kapsama sahip olduğuna kail olanlar aynı zamanda âmma dayalı verilen hükümlerin de kat'̂̂ olduğunu ifade etmişlerdir. Cessâs'tan önce de bu konunun tartışıldığg onun ifadelerinden anlaşılmaktadır. Ancak âmmın hükme delaletinin kat'̂̂ olduğunu ilk temellendirenlerden birisinin Cessâs olduğunu kesin olarak bilmekteyiz. $\mathrm{O}$, âmmın hükme delâletinin kat'îliğini ispatlamak için şöyle bir diyalektiğe başvurur:

olabilir. Âm ile kastedilenin husus olduğunu gösteren bir delilin varlığı halinde bu, mümkündür. Delil bulunmaksızın âmmın hususi bir kapsama sahip olduğunu ileri sürmek ise doğru değildir. Ayrıca ona göre bir insanın hem müjdeleyici (va'd) hem de azapla ilgili (vaîd) âyetleri umum bir kapsama sahip olarak değerlendirmesi, kendisiyle çelişmesine sebep olacaktır. Zira bir yandan şirk dışındaki tüm günahların affedileceğine kani olmaktadır. Diğger yandan büyük günah işleyenlerin yerinin Cehennem olduğunu kabul etmek zorunda kalmaktadır. bk. Mâtürîdî, Tevbîd, s. 442.

35 bkz. Zysow, "Mu’tazilism and Maturidism in Hanafi Legal Theory”, s. 257.

36 Nesefî, Kesf, I, 164-166.

37 Üsmendî, Bezl, s. 176-177; Habbâzî, Muğnî, s. 99-101.

38 bkz. Zysow, "Mu’tazilism and Maturidism in Hanafi Legal Theory", s. 257. 
Lafzın, içeriğinin en azına delâlet ettiğini düşünenler, kendilerini şöyle savunabilirler: "Lafzın, içeriğinin en azına göre hüküm verirsen bu yakīnî bir bilgi olur. Bunun ötesi ise şüphelidir." Onların bu savunmaları şu şekilde cevaplandırılır: "Lafzın, içeriğinin en azına delâletinin yakīn ifade ettiğini nereden bildin? Vakıf görüşünü savunanlar da benzer şekilde lafzın, içeriğinin en azına delâletini şüpheli görmüşlerdir. $O$ halde lafzın içeriğinin en azına delâlet ettiğini savunanların bunu lafzın dışında bir delille desteklemeleri gerekir. Böyle bir şey de bulunmadığına göre lafzın içeriğinin en azına delâlet ettiğine ilişkin olarak lafızdan başka bir delil bulunmadığı anlaşılmış olmaktadır. Lafzın ise içeriğinin çoğuna delâleti nasılsa içeriğinin azına delâleti de aynıdır. Bu durumda lafzın içeriğinin azına delâlet ettiği gibi çoğuna da delâlet ettiği kabul edilmelidir. Böylece âmmın hükmünün husus olduğu görüşünün de yanlış olduğu ortaya çıkmış olmaktadır. ${ }^{39}$

Görüldüğü gibi Cessâs; âmmın, genel bir kapsama delâletinin kat'iyyetini muhalif görüşün dayanaklarını çürütmek suretiyle ispatlamaktadir.

Debûsî̀ye göre de gerek emir ve nehiylerde ve gerekse haberlerde âmmın kesinlik açısından hâstan bir farkı bulunmamaktadır. O; bunu, mezhebin kurucu imamlarınin ictihadlarına dayandırarak ispatlama cihetine yönelir. Buna göre Hanefîler, Fâtiha olmaksızın da namazın caiz olacağını "O halde Kur'an'dan kolaymıza geleni okuyun." âyetinin genel kapsamlı oluşuna dayalı olarak söylemişlerdir. Haber-i vâhid olması sebebiyle de "Fâtihasız namaz olmaz"." hadisiyle bu âyetin genel kapsamlı oluşunu aynı mertebede değerlendirmemişlerdir. Haber, hâs; âyet, âm olmasına rağmen âyeti tercih etmişlerdir. Ayrıca Debûsî, âmmin genel bir kapsama delâletinin kat'iyyetini aklî olarak da temellendirir:

Eğer âm lafzın hükmünün yerine getirilmesi başka delillerin varlığını gerekli kılsaydı bu deliller ve ahvâl karînesi olmaksızın âm lafizla amel edilemezdi. Halbuki şerîat, kiyâmete kadar bağlayıcıllğını sürdürecektir. Şerîate uymanın vücûbiyeti de Kitâb ve sünnetle sabit olmaktadır. Eğger bu deliller olmaksızın kendi başına naslar hüccet kabul

\footnotetext{
Cessas, el-Fusul, I, 111-112.

40 el-Müzzemmil 73/20.

41 Müslim, "Salât", 34-36, 38, 41; Ebû Dâvûd, "Salât", 132; Tirmizî, "Salât", 116.
} 
edilmeseydi, bu delillerin nakli hakkında sahâbenin suskun kalması helâl olmazdi. Nitekim haberlerin nakliyle ilgili olarak sahâbe ihtilafa düştüğünde Hz. Ebû Bekr’in (ö. 13/634) şöyle söylediği bilinmektedir: "Bir konuda ihtilafa düşmüşseniz bilin ki sizden sonrakiler o konuda daha büyük bir ihtilaf içerisinde olacaklardır. Cevabını aradığınız konuda rivâyette bulunmayın ve şöyle demekle yetinin: "Allah'ın kitabı yanınızdadır. Onun helâl kıldığını helâl kılın, haram kıldığını haram kılın." Hz. Ebû Bekr'in bu sözüne itiraz eden de olmamıştır. Böylelikle kesin olarak bilinmektedir ki sahâbe için hüccet olduğu zannedilen ahvâl olmadan da Kitab kendi başına hüccettir. ${ }^{42}$

Debûsî'nin ifadelerinden anlaşılan o ki; âmma dayalı olarak hüküm verebilmek için bir başka delile gerek duyulmamaktadır. Âmmın genel bir kapsama sahip olduğunda Serahsî ve Fahrülislâm Pezdevî'nin Debûsî̀yi takip ettiğine daha önce değinmiştik. Âmmın hükme delâletindeki kat'iyyete ilişkin olarak da her iki âlim, Debûsînnin izinden yürümektedir. ${ }^{43}$

Lâmişîye ve Alâeddin Semerkandî̀ye göre ise ashâbü'l-umum, âmmın kapsamına giren her bir fertle ilgili olarak amelin ve itikadın gerekliliği konusunda ihtilafa düşmüştür. Hanefîler arasında çoğunluk; âmmın kapsamına giren her bir fertle ilgili olarak ameli ve itikadı gerekli görmektedirler. Mâturîdî’nin öncüsü olduğu Semerkand âlimlerine göre ise âmmın kapsamına giren her bir fertle ilgili olarak amel gereklidir. Ancak âm ile kastedilenin umum mu yoksa husus mu olduğu ihtilaflı olduğu için âmma dayalı olarak itikadi gereklilik sabit olmamaktadır. ${ }^{44}$

Âmmın hükmüne ilişkin söz konusu ihtilafa Üsmendî değinmediği için onun bu konudaki görüşünü tespit etmek zorlaşmaktadır. İstiğrak1 âmmın şartı olarak görmesinden ve âmmın genel bir kapsama sahip olduğunu açık bir şekilde ifade etmiş olmasından yola çıkıldığında âmmın hükme delaletini kat'î olarak gördüğü söylenebilir. Ancak bu konuda Habbâzî’nin tavrı nettir. Ona göre âm, kapsadiğ1 fertlerle ilgili olarak yakīnî bilgiyi gerekli kılar. Çünkü sîga hangi mâna için

42 Debûsî, Takvîm, s. 98.

43 Serahsî, Usûl, I, 132-136; Fahrülislâm Pezdevî, Usûl, s. 69-73.

44 Lâmişî, el-Kitâb, s. 124-125; Semerkandî, Mî̌ân, I, 385-386. 
konulmuşsa o mâna bağlayıcılık kazanmış olmaktadır. Yeter ki bunun böyle olmadığını gösteren bir delil bulunmasın. Ona göre insanın kızlarıyla, anneleriyle evlenmesinin yasak olması ve boşanmış kadınların iddet yükümlülüğü âm lafızların genel bir hükmü gerekli kılmalarına dayalıdır. Âm lafızdan hususi bir anlam çıkarılması mümkün değildir. Bu yüzden âm lafizların kıyasla ve haber-i vâhidle tahsis edilmeleri de caiz değildir. Buna dayalı olarak Hanefîler, süt emzirmede az çok arasında bir ayrım gözetmemişlerdir. Zira Allah'ın şu sözü âmdır ve genel bir hüküm

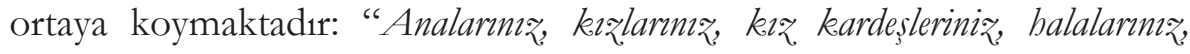

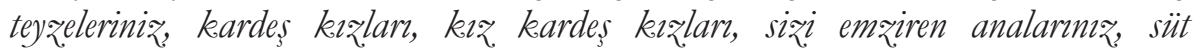
bacularmı, eşlerinizin analar, kendileriyle birlestiüziniz eşlerinizden olup evleriniżde bulunan üvey kizlarmı size haram kılındr. Eğer onlarla (nikâhlanı da) benüz. birleşmemisseniz, kızlarm almanızda siž bir mahzur yoktur. Kendi sulbünüzden olan oğullarmı̨n eşleri ve iki kız kardeşi birden almak da size haram kilındi; ancak geçen gecmiştir. Allah çok bağgşlaync ve esirgeyicidir." 45 Bu âyette âmmin, İbn Zübeyr'in "bir ya da iki defa süt emzirmenin süt haramlığına dayalı hükümleri tesis etmeyeceği” yönündeki rivâyetiyle tahsisi câiz görülmemiştir. ${ }^{46}$

\section{II. Âmla İlgili Tartışma Kelâmî Tartışma: Büyük Günah İşleyenin Durumu}

Hz. Peygamberin vefatından sonra ortaya çıan ve hilâfet konusundaki ihtilaflardan kaynaklanan siyasi tartışmalar, fitne olaylarını meydana getirmiştir. Hz. Osman'in (ö. 35/656) şehit edilmesi, akabinde Cemel vak'ası ve Sıffin savaşı ile devam eden olaylar; Müslümanları karşı karşıya getirmiştir. Bunun tabî̂ neticesi olarak; Müslümanların birbirini öldürmesi gibi elim bir durum ortaya çımıştır. ${ }^{47} \mathrm{Bu}$ tarihi ve siyasi olaylara paralel bir şekilde Müslümanlardan büyük günah işleyenlerin dînî durumları yoğun bir tartışma alanı bulmuştur. Âmmın kapsamıyla ilgili tartısmaların yoğunluk kazanmasında etkili olan bu problem, aynı zamanda naslarda geçen âm lafızların kapsamı ile de doğrudan ilişkilidir.

\footnotetext{
en-Nisâ 4/23.

46 Habbâzî, Muğnî, s. 99-101.

47 Zikredilen bu olaylarla ilgili detaylı bilgi için bk. İbn Kesîr, el-Bidâye ve'n-nihâye (thk. Abdullah b. Abdülmuhsin et-Türkî), Cîze 1417/1997, X, 270-570.
} 
Çünkü söz konusu problem, Kur'an'daki genel kapsamlı bazı âyetlerin anlaşılması gayesine matuftur. Bu âyetlerden bazılları şöyledir:

"Allah, kendisine ortak koşulmasını asla bağışlamaz; bundan başkasını, (günahları) dilediği kimse için bağışlar. Allah'a ortak koşan kimse büyük bir günah (ile) iftira etmiş olur." ${ }^{48}$

"Allah, kendisine ortak koşulmasını asla bağışlamaz; ondan başka günahları dilediği kimse için bağışlar. Kim Allah'a ortak koşarsa büsbütün sapıtmıştır." ${ }^{49}$

"De ki: Ey kendi nefisleri aleyhine haddi aşan kullarım! Allah'ın rahmetinden ümit kesmeyin! Çünkü Allah bütün günahları bağgşlar. Şüphesiz ki O, çok bağışlayan, çok esirgeyendir." ${ }^{50}$

"O ateşe, ancak yalanlayıp yüz çeviren kötüler girer." 51

Görüldüğ̈̈ gibi bu âyetlerdeki âm lafizlarla, Müslümanlardan büyük günah işleyenlerin durumu açıklı̆ga kavuşmaktadır. Nitekim büyük günah işleyen Müslümanlarla ilgili sünnî yaklaşım da şirk dışında bütün günahların bağışlanabileceğine söz konusu âyetlerin genel kapsamlı olarak anlaşılmasına dayalıdır. ${ }^{52}$

Âm lafizların kapsamı ile büyük günah işleyenler arasındaki bu bağlantıya en açık bir şekilde Cessâs işaret etmiştir. Ona Ebü't-Tayyib b. Şihâb, Kerhî’nin haberlerde vakıf görüşünü benimsediğini söylediğinde ilk tepkisi şöyle olmuştur:

-O halde Kerhî, ehli milletin fâsıklarının âhirette ebedi olarak cezalandırılmasına (vaîd) ilişkin olarak da vakıf görüşünü tercih etmiştir.

Ebü’t-Tayyib b. Şihab ise Kerhî’nin görüşünün zaten böyle olduğunu, ayrıca Ebû Saîd el-Berdê̂’nin (ö. 317/929) de hem haberlerde hem de emir ve nehiylerde vakıf görüşüne kail olduğunu ifade etmiştir.

\footnotetext{
en-Nisâ 4/48.

en-Nisâ 4/116.

ez-Zümer 39/53.

1 Leyl 92/15-16.

52 Mâtürîdî, Tevbîd, s. 430-432.
} 
$\mathrm{Bu}$ nakle ilişkin olarak Cessâs, şöyle bir değerlendirmede bulunmuştur:

Anlattığı şeylerde Ebü't-Tayyib güvenilirdir. Zira hem Ebû Saîd el-Berdeî ile hem de ilk dönemde öne çıkan âlimlerle görüşme imkânı bulmuştur. Ancak ben, Kerhî’nin böyle söylediğini -daha doğrusu emir ve nehiylerle haberler arasında bir ayrım yaptığını- hiç işitmedim. $O$, mutlak olarak umum görüşünü benimsemiştir. ${ }^{53}$

$\mathrm{Bu}$ nakil, âm lafizların kapsamı ile büyük günah işleyen Müslümanların durumu arasındaki ilişkiyi göstermesi açısından önemlidir. Ancak bunu değerlendiren Cessâs, Kerhî ile ilgili haber veren kişinin güvenilirliğini teyit etmekle beraber haberin içeriğine itirazda bulunmaktadır. Cessâs'a göre Kerhî, âm lafizların genel bir kapsama sahip olacağına kanidir ve bu görüşünde yalnız da değildir. Ona göre gerek Ebû Hanîfe gerekse mezhebin kurucu imamlarından diğerleri âm lafızların genel bir kapsama sahip olduğu konusunda görüş birliğine varmışlardır. Cessâs, kendisinin de desteklediği bu yaklaşıma mezhebin ictihadlarından pek çok örnek vermiştir. Bu çerçevede büyük günah işleyen Müslümanların affedilebileceğine dair Ebû Hanîfe'nin görüşü, Cessâs'a göre, Allah'ın affedici olduğunu vurgulayan âyetlerin genel kapsamlı olarak değerlendirilmesine bağlıdır. Bu durumda Ebû Hanîfe'nin haberlerde vakıf görüşünü benimsediğini ileri sürenler de yanılmış olmaktadır. Şöyle ki; Ebû Hanîfe, delil olmaksızın haberlerde umum ya da husus kastedildiğine dair kat'i bir görüş ortaya koymamaktadır. Çünkü ondan nakledilen meşhur görüş; büyük günah işleyenlerin, Cehennem'de ebedi olarak cezalandırılmaları hakkında kat'î bir görüş ortaya koymama ve ahirette affedilmelerinin caiz olduğu yönündedir. ${ }^{54}$ Ancak Ebû Hanîfe'nin büyük günah işleyenin akıbetine ilişkin görüşü böyle olsa da bu; haberlerde vakıf görüşünü benimsemesinden ileri gelmemektedir. Onu böyle düşünmeye yönelten

53 Cessâs, el-Fusûl, I, 102.

54 Cessâs, el-Fusûl, I, 102. Ebû Hanîfe'nin kendi eserlerinde de bu düşünce açık bir şekilde ifade edilmiştir. bk. Ebû Hanîfe, Imam-ı A'zam'ın Beş Eseri (trc. Mustafa Öz), İstanbul 1992, s. 57. 
temel faktör, ateşte ebedi olarak kalacak olanların kâfirler olmasıdır. Nitekim yukarıda serdedilen âyetler de bu anlayışı desteklemektedir. ${ }^{55}$

Cessâs, bunu teyit eden bir açıklamayı Îsâ b. Ebân'a (ö. 221/836) da isnat etmektedir. Buna göre Îsâ b. Ebân şöyle demiştir:

Biz, ehl-i milletin fâsıklarının cehennem azabıyla cezalandırılmalarına ilişkin olarak vakıf görüşünü tercih ettik. Çünkü ilgili âyetler, ehli milletin fâsıklarının cehenneme gireceğini göstermektedir. Ancak biz bu konudaki diğer âyetleri de dikkate alarak onlara azap edilmesinin de mağfiret edilmesinin de caiz olacağına hükmettik. Onların işleriyle ilgili hükmü Allah'a havale ettik ve kesin bir hüküm vermekten kaçındık. $^{56}$

Burada "ehl-i milletin fâsıkları" ifadesiyle kastedilenin "Müslümanlardan büyük günah işleyenler" olduğunda tereddüt bulunmamaktadır. Bu ifadelerden anlaşılan o ki; büyük günah işleyenlerin affedilmeleri de azaba çarptırılmaları da mümkündür. Ayrıca Îsâ b. Ebân'ın "biz" diyerek ifade ettiği bu düşüncelerin, mezhebin kurucu imamlarına isnadında da bir sorun bulunmamaktadır. Zira o; Muhammed b. Hasan Şeybânînnin, hem öğrencisi hem de eserlerinin pek çoğunun râvisidir. Bu durumda Ebû Hanîfe'ye ve önde gelen öğrencilerine göre âmmin genel bir kapsama sahip olduğunu ifade etmemiz mümkün gözükmektedir. Nitekim Cessâs, -bunu ispat sadedinde- mezhebin önde gelen âlimlerinden hiçbirisinin buna aykırı bir görüş beyan etmediğini ifade etmiştir. ${ }^{57}$

Esasen Ebû Hanîfe'nin konuya ilişkin görüşü tereddüde mahal bırakmayacak ölçüde açıktır. Zira ona göre Peygamberlerin ve cennetlik olduğu bildirilen kimselerin cennete gidecekleri müsellemdir. Müşriklerin cehennemlik olduklarında da herhangi bir şüphe bulunmamaktadır. Günahkâr müminlerin durumuna ilişkin olarak ise ilahi af umulur. Zira

\footnotetext{
55 Bu ayetlerle ilgili örnekler için bk. en-Nisâ 4/48 ve 116; ez-Zümer 39/53; Leyl 92/15-16.

55 ez-Zümer 39/53.

55 Leyl 92/15-16.

56 Cessâs, el-Fusûl, I, 103.

57 Cessâs, el-Fusûl, I, 103.
} 
günah, kişiyi dinden çıkarmaz. Ancak bu durumdaki kimselerin azaba çekilmeyecekleri söylenemez. ${ }^{58}$ Nitekim Allah'ın, dilediği kimsenin şirk dışındaki günahlarını bağışlayacağını belirten âyetler de bu düşünceyi desteklemektedir. ${ }^{59} \mathrm{Bu}$ âyetlerden Ebû Hanîfe'nin vardığ1 sonuca ulaşmamız, âyetlerde geçen âm lafizların genel bir kapsama sahip olduğunu kabul etmemizi gerektirmektedir.

Görüldüğü gibi Ebû Hanîfe, günah işleyen kişiyi mümin olarak değerlendirmiştir. Bilindiği üzere buna muhalif bir bakış açısı olarak Hâricî ve Mu’tezilî yaklaşım, günah işleyen kişiyi mümin olarak görmemektedir. ${ }^{60}$ Dikkat çekici olan, Ebû Hanîfe'nin günahkârların durumu hakkında herhangi bir yargida bulunmayarak affedilmelerini ya da cezalandırılmalarını Allah'a havale etmesinin mürcî̂ bazı unsurları ihtiva etmesidir. Nitekim o da söz konusu düşüncelerinden dolayı "mürcî̂" olarak nitelendiğini ima etmiştir. ${ }^{61}$ Ancak ona bu nitelemeyi yapanları bid'at ehli olarak görmesi, Ebû Hanîfe'nin yaşadığ1 toplumda Mürcie hakkında olumsuz bir algının varlığını düşündürmektedir. Diğer yandan büyük günah işleyen müminin durumuna ilişkin olarak Mürcie’ye birbirinden farklı pek çok görüş isnad edilmiş olduğunu göz önünde bulundurmak gerekmektedir. Bu konuda Mürcie'ye isnad edilen görüşler içerisinde en yaygın olanlarından birisi, imanın yanında amelin zararı olmayacağından dolayı ehl-i kıbleye azap edilmeyeceği yaklaşımıdır. ${ }^{62}$ Ebû Hanîfe, günahkâr müminin günahından dolayı azaba çekilmesini ihtimal dışı görmeyerek bu yaklaşımı reddetmiştir. Netice itibariyle Ebû Hanîfe'nin mürciî olarak nitelenmesinin yanıltıcı olabileceğini ancak onun düşüncesinde mürcî̀ bazı unsurların var olduğunu kabul etmemiz lazım gelmektedir. ${ }^{63}$

58 Ebû Hanife, Imam-ı A'zam'ın Beş Eseri, s. 68.

59 en-Nisâ 4/48; et-Tevbe 9/102.

60 Kādî Abdülcebbâr, Şerbu'l-Usûli'l-bamse (trc. İlyas Çelebi), İstanbul 2013, II, 620. Konuyla ilgili âyetlerin Mu'tezilî yorumu ile ilgili değerlendirmeler için bk. Yakup Biyıkoğlu, Kur'an'in Selefí Yorumu, İstanbul 2015, s. 314-320; a. mlf. , Esbâb-ı Nü̃ûl ve Kur'ân'in Anlașılması, İstanbul 2005, s. 111-113.

61 Ebû Hanîfe, Imam-ı A'zam'ın Beş Eseri, s. 68.

62 Eş'arî, Makālât, I, 225-228.

63 Bu yaklaşımla ilgili değerlendirmeler için bk. Zysow, "Mu’tazilism and Maturidism in Hanafi Legal Theory", s. 235. 
$\mathrm{Bu}$ yaklașımın Cessâs üzerindeki etkisi ise daha fazla önem taşımaktadır. Çünkü her ne kadar Hanefîler ve Mu’tezile, âm lafızlann genel bir kapsama sahip olduğu noktasında birleşmiş olsalar da konunun kelâmî yönünde bir görüss birliğinden bahsetmek mümkün gözükmemektedir. Yukarıda da değinildiği üzere Hanefîlere göre büyük ya da küçük günah, kişiyi imandan çıkarmaz. Büyük günah işleyenlerin cehennemde ebedi olarak kalmayacakları da kesin olarak bilinmektedir. Mu’tezile'ye göre ise büyük günah işleyen kişi, imandan çıkar. Ancak inanç esaslarını inkâr etmiş olmadığından dolayı kâfir olarak değil fâsık olarak nitelenir. $\mathrm{Bu}$ çerçevede büyük günah işleyen kişinin durumuna ilişkin olarak Hanefîlerle Mutezile arasında köklü bir ayrışmanın varlı̆̆ açık bir şekilde görülmektedir. Bundan daha da önemlisi, Mu'tezilî inanç sisteminin en temel esası kabul edilen söz konusu meselede Cessâs'ı́n Mu'tezile karşıtı görüşü açık bir şekilde temellendirmiş olmasıdır. Bu bilgi, tek başına Irak Hanefîlerinde ve özellikle Cessâs'ta Mu'tezilî etkinin varlığına yönelik tezi reddetmek için kifâyet etmeyebilir. Ancak büyük günah işleyenin durumu, Mu’tezilî inanç sisteminde belirleyici bir mesele olarak görüldüğünde Cessâs'ın bu konuda Mu’tezile karşıtı bir görüşü benimsemiş olmasının önemi artmaktadır. Burada Mu'tezile'nin kurucusu olarak kabul edilen Vâsıl b. Atâ'nın (ö. 131/748), Hasan-1 Basrî̀nin (ö. 110/728) meclisinden büyük günah işleyenin durumuna ilişkin bir sualin neticesinde ayrıldığını (i'tizẩ) hatırlamamızda fayda vardır. ${ }^{64}$

\section{III. Âmmın Dil İlimleriyle İlişkisi: Sîga-Mâna İrtibatı}

Araştırmanın bu bölümünde âm lafızlar, dil ilimleri çerçevesinde incelenecektir. Dil ilimleri içerisinde âmla ilişkili olmaları cihetiyle öne çıkanlar, nahiv ve lügattır. Bu incelemeyle amaçlanan, söz konusu alanlarda âm lafizların kapsamı ile ilgili elde edilen bilgilerin, Hanefî usûlünde âmmın kapsamına olan etkisine açıklık kazandırmaktır. Ayrıca dil ilimlerinde ve fikıh usûlünde konunun ele alınışı açısından bir uyumun varlığ1 da bu inceleme neticesinde belirginlik kazanmış olacaktır.

Âm lafızlarla ilgili olarak nahiv ve lügat ilimlerindeki tartışmalar, bu lafızların kapsamına ilişkin Hanefî usûlündeki yaklaşımların ortaya

64 Bu anekdotla ilgili detaylı bilgi için bk. Abdülkahir el-Bağdâdî, Mez̧hepler Arasindaki Farklar (trc. Ethem Ruhi Fiğlalı), Ankara 2005, s. 86. 
çıkmasını sağlamıştır. Bunun tabii bir neticesi olarak Hanefî usûl müellifleri, âm lafızların genel bir kapsama sahip olduğuna okuyucularını ikna etmek için nahiv ve lügat ilimlerine siklıkla atıfta bulunmuşlardır. ${ }^{65}$ Âm lafizların kapsamıla ilgili olarak Hanefilerle Mu’tezile arasındaki görüş birliğinin anlaşılır hale gelmesi de bunun göz önünde bulundurulmasını gerekli kilmaktadır. Gerek Hanefiler gerekse Mu'tezile âm lafızların genel bir kapsama sahip olduklarını ifade ederken nahiv ve lügat ilimlerinde ulaşılan sonuçlara istinad etmişlerdir. ${ }^{66}$ Buna dayalı olarak da her iki grubun ittifak ettikleri alan, fikıh usûlüyle sınırlı kalmıştır. Bir başka deyişle konunun kelâmî yönünde Hanefîler ve Mu’tezile arasında bir ittifak vuku bulmamıştır. Nitekim büyük günah işleyenin durumuna ilişkin olarak söz konusu grupların görüş ayrıllğıına düşmüş olduklarına daha önce değinmiştik.

Hanefî usûlünde âm, içeriğinde birçok konu başlı̆̆ı bulunan bir tema olarak incelenmiştir. Bu konu başlıkları içerisinde nahivle ve lügatla en güçlü ilişki içerisinde olanı ise âm lafızlardaki sîga-mâna ilişkisidir. Bu konuya ilişkin olarak Hanefî usûl müelliflerinin ortaya koydukları görüsslerin tamamına yakını, nahiv ve lügat ilimlerinde ulaşılan sonuçlara dayalıdır. ${ }^{67}$ Ayrıca bu sonuçlar, âmmın genel bir kapsama sahip olduğu yönündeki Hanefî bakış açısını da destekleyici niteliktedir.

Âm lafizlardan kimileri hem sîgası hem de mânası ile birlikte âm kabul edilirken kimileri sîgasıyla değil yalnız mânasıyla âm kabul edilmektedir. Hanefî usûlünde bu ilişkiyi açığa çıkaran pek çok tasnif yapılmıştır. Bunlar arasında -tespit edebildiğimiz- ilk tasnif Fahrülislâm Pezdevî'ye aittir. ${ }^{68}$ Fahrülislâm Pezdevî'den sonra Alâeddin Semerkandî ve Üsmendî gibi âlimler de âm lafızları sîga-mâna ilişkisi açısından tasnif

65 Buna örnek teşkil eden eserlerle ilgili olarak bk. Fahrülislâm Pezdevî, Usûl, s. 69-73; Semerkandî, Mî̃ân, I, 385-386; Üsmendî, Bęl, s. 176-177.

66 Fahrülislâm Pezdevî, Usûl, s. 69-73; Semerkandî, Mî̃ân, I, 385-386; Üsmendî, Bę̧l, s. 176-177; Habbâzî, Muğnî, s. 99-101.

67 Bu durum; âmmı, esas itibariyle nahiv ve lügat ilimleriyle ilgili bir mesele olarak görmelerinden ileri gelmektedir. Bkz. Bunu ortaya koyan aç1klamalar için bk. Cessâs, el-Fusûl, I, 104-105; Lâmişî, el-Kitâb, s. 122-124; Semerkandî, Mî̃ân, I, 365366.

68 Fahrülislâm Pezdevî, Usûl, s. 69-73. 
etmişlerdir. ${ }^{69} \mathrm{Bu}$ tasnifler incelendiğinde Alâeddin Semerkandî ve Üsmendî tarafindan yapılan tasniflerin, Fahrülislâm Pezdevî'nin tasnifinden daha kapsamlı olduğu kolaylıkla anlaşılmaktadır. Nitekim Fahrülislâm Pezdevî̀nin tasnifinde sîga açısından âm olan pek çok lafza yer verilmemiş olması da bunu destekleyici niteliktedir.

Âm lafızların sîga-mâna ilișkisi üzerine yapılan tasniflerin en kapsamlısının Alâeddin Semerkandî̀ye ait olduğunu söylemek mümkündür. $\mathrm{Bu}$ tasnifin öne çıkan bir yönü de âmmın şartı olarak istîâbın değil ictimâın esas alınmasıdır. ${ }^{70}$ Ayrıca Alâeddin Semerkandî’den sonra yapilan tasniflerde de bu tasnifin izleri görülebilmektedir. Bu çerçevede gerek Üsmendî’nin gerekse Habbâzî’nin tasnifi onun bir özeti niteliğindedir. $^{71} \mathrm{Bu}$ araştırmada da esas alınan tasnif, Alâeddin Semerkandî'nin tasnifi olmuştur. Ancak Hanefi usûl müelliflerinden diğerlerinin tasniflerine de bu tasnif içerisinde yer verilmiştir.

Buna göre sîga-mâna ilişkisi açısından âm lafizlar; -vaz itibariylekendi başına âm olanlar ve başkalarıyla birlikte âm olanlar şeklinde ikiye ayrilmaktadır.

\section{A. Kendi Başına Âm Olan Lafızlar}

Bu lafizlar, genel bir anlam ifade etmek için bir başka kelimeye ya da karineye ihtiyaç duymazlar. Bunlar, sîga-mâna bütünlüğüyle âm olanlar ve sadece mânasıyla âm olanlar şeklinde iki kısma ayrılmaktadır.

\section{Sîga-Mâna Bütünlüğüyle Âm Olanlar}

Bu türe girenler içerisinde lafız genel bir anlamı ifade etmek üzere konulduğu gibi bu lafzın içeriğindeki mâna da genel bir nitelik taşımaktadır. Cemîler ve cins isimler buna örnek teşkil etmektedir.

\section{a. Cemî̀ İsimler}

Cem'; dağınık olan bir şeyi toplayıp bir araya getirmek anlamına gelmektedir. Bu kelime, insan topluluğunu ifade eden bir isim olduğu gibi "cemea" fiilinin masdarı olarak da kullanılmaktadır. Ayrıca hayvan ya da

\footnotetext{
69 Semerkandî, Mî̃ân, I, 385-386; Üsmendî, Bęৃl, s. 176-177.

70 Semerkandî, Mî̃ân, I, 385-386.

71 Üsmendî, Beql, s. 176-177; Habbâzî, Muğnî, s. 99-101.
} 
bitki topluluklarını ifade etmek üzere de bu kelime kullanılmaktadır. ${ }^{72}$ Tesniye ile cemî' arasındaki fark; tesniyenin iki ferde delâlet etmesi, cemînin ise ikiden daha fazla ferde delâlet etmek üzere kurulmuş olmasıdır. ${ }^{73}$ Nitekim lügat âlimlerinin kelimeyi müfred-tesniye ve cemî olmak üzere üçlü bir ayrıma tabi tutmaları da bunu destekleyici niteliktedir. Zira bu tasnif, sadece cemîleri ifade etmek üzere bir sîganın var olduğunu açıkça ortaya koymaktadır. ${ }^{74} \mathrm{Bu}$ lafizların içerisine ricâl, nisâ, muslimûn, muslimât gibi cemîler girmektedir. ${ }^{75}$ Tanımdan da anlaşıldığı üzere bu lafızların sîgası ikiden fazla sayıda ferdi ifade etmek üzere konulduğu gibi mânası da böyle bir kapsama sahiptir. Bu lafızlar, içerdikleri fertlerin tamamını kapsayıcıdır.

Âmmın, içeriğinin tamamını kapsadığını daha önce belirtmiştik. Ancak içerdiği fertlerin tamamını kapsamakla birlikte bunlardan üç tanesine delâleti evlâdır. Bu yüzden bir adam "köleler satın alırsam şöyle olsun" ya da "kadınlarla (nisa) evlenirsem şöyle olsun" dese sözlü tasarrufu üçten fazlası hakkında da geçerli olur. ${ }^{76}$

Cemî isimlerin harfi tarif alması halinde ise harfi tarif, ahd değil cins anlaminda kabul edilmektedir. Zira cemî isimlerde ahd bulunmamaktadır. Bu yüzden harfi tarif alan cemî isimlere cins anlam verilmiştir. Cins de çoğul bir kapsama sahip olduğu için "kadınlarla evlenirse boş olsun" gibi sözler söyleyen kişinin karısının boş olduğu kabul edilmiştir. Zira bu sözlü tasarruf, tek bir kadın hakkında vaki olabileceği gibi birden fazla kadın hakkında da geçerli olabilmektedir. Çünkü buradaki âm lafız, artık cins isim konumuna gelmiştir. ${ }^{77}$

\section{b. Cins isimler}

Cins isim, tek bir fert üzerinde vaki olabildiği gibi birden fazla fert de cins ismin kapsamı altına girebilmektedir. Hz Âdem'in tek başına

\footnotetext{
72 İbn Manzûr Lisân, “cemea” md.

73 Enbârî, Esrârü'l-Arabiyye (thk.Muhammed Behcet el-Baytâr), Dımaşk 1357/1957, I, 47-48.

74 Lâmişî, el-Kitâb, s. 122-124.

75 Semerkandî, Mî̃ân, I, 361.

76 Semerkandî, Mîâan, I, 362.

77 Semerkandî, Mî̃âan, I, 362.
} 
bir cinsi temsil etmesi, cins ismin tek bir fert üzerinde vaki olmasina örnek teşkil etmektedir. Bu durum; cinsin, genel bir kapsama sahip olduğunu açık bir şekilde ortaya koymaktadır. Nitekim birisinin su içmeyeceğine yemin etmesi halinde -ister az isterse çok- su içmesi halinde yemini bozulmaktadır. Zira burada "su" cins isim konumunda bulunmaktadır. $^{78}$

\section{Sadece Mânasıyla Âm Olan Lafızlar}

Topluluk isimleri ve müfred isimler; kalıp, lafız ya da sîga itibariyle tekil bir durumda bulunmaktadırlar. Ancak bu isimler ayn zamanda genel bir kapsamı ifade etmektedirler.

\section{a. Topluluk İsimleri}

Bu isimler, müfred sîga ile cemî bir anlam ortaya koymaktadırlar. "Reht" ve "kavm" kelimeleri buna örnek teşkil etmektedir. Bu çerçevede İbn Abbas, şu âyette geçen "tâife" kelimesinin tek bir ferde olduğu gibi birden fazla ferde delâletini de mümkün görmektedir: "Müminlerin hepsinin toptan sefere çlkmalar doğru değildir. Onlarn her kesiminde bir grup (tâife), dinde (dinî ilimlerde) genis bilgi elde etmek ve kavimleri (savastan) döndüklerinde onlar ikaz, etmek için geride kalmahdır. Umulur ki sakimilar."79 Âyetteki "tâife" kelimesinin genel bir kapsama sahip olduğunun kabul edilmesi, cemaat alâmeti taşıyan bir cins isim olmasından ileri gelmektedir. ${ }^{80}$

\section{b. Müfred İsimler}

İsim fiil veya masdar olarak kullanılan müfred lafızlar, bu türün önemli bir kısmını teşkil etmektedir. Bu lafızlar, müfred bir sîga içerisinde cemî' bir anlam ifade etmektedirler. Meselâ birisi karısına "enti tâlikun talâkan" dediğinde üç talaka niyet etmişse bâin talakın vâki olduğu kabul edilmektedir. Zira bu ifadede geçen "talâkan" ifadesi müfred bir sîga içerisinde cemî' bir anlam ifade etmektedir. Benzer şekilde âyette geçen ve yok olma anlamına gelen "subûr" masdarı da kesret ile nitelenmiştir. ${ }^{82}$

\footnotetext{
Fahrülislâm Pezdevî, Usûl, s. 67.

et-Tevbe 9/122.

Fahrülislâm Pezdevî, Usûl, s. 68.

1 el-Furkân 25/14.
} 


\section{B. Başkalarıly Birlikte Âm Olanlar}

$\mathrm{Bu}$ tür içerisine giren lafızlardan bazıları herhangi bir karineye ihtiyaç duyulmaksızın anlaşılabilmektedir. Bazılarının ise anlaşılabilmesi, bunu sağlayan bir karinenin varlığına bağlıdır.

\section{Karine Olmaksızın Anlaşılabilenler}

Anlaşılması herhangi bir karineye bağlı olmayanlar içerisine harfi tarifli isimler ve nekre isimler girmektedir.

\section{a. Harfi Tarifli İsimler}

Harfi tarif olarak kullanılan elif lam takısı; ahd, cins ve istiğrak için kullanımına göre üç kısma ayrılır. Ahd için kullanıldığında isim ya daha önce zikredilmiş olmalıdır ya da zikredilmediği halde zihnen bilindiği kabul edilmelidir. "Câe'l-kâdî" ifadesinde konuşanlarca bilinen bir kadı varsa özel olarak zikredilmesine gerek kalmaksızın zihnen var olduğu kabul edilmektedir."Er-racul efdalu mine'l-mer'e" denildiğinde kastedilen belirli bir erkeğin belirli bir kadından üstünlüğü değilse bu kelimelerdeki harfi tarifin cins için kullanılmış olduğu kabul edilmektedir. $\mathrm{Bu}$ durumda kastedilen, cins olarak erkeğin kadından üstünlüğüdür. Buradan her bir erkeğin her bir kadından üstün olduğu anlamı çıkarılamaz. Çünkü bu, gerçeğe uygun değildir. Zira erkekten üstün olan kadınların olması muhal değildir. İstiğrak için olan harfi tarif ise hangi ismin başına geldiyse o ismin kapsamı altına giren fertlerin tamamını kapsamaktadır. Mesela "İnsan raynf yaratılmıștır." cinsi kastedilmiştir. ${ }^{84}$

Birçok isim, harfi tarif almaksızın has bir kapsama sahipken harfi tariften sonra âm olarak değerlendirilmektedir. "İnsan" ve "racül" kelimeleri buna örnek teşkil etmektedir. Bu kelimeler, harfi tarif almaksızın tek bir insana ya da adama delâlet ettikleri halde harfi tarif

Semerkandî, Mî̃ân, I, 362.

en-Nisâ 4/28.

84 İbn Hişâm en-Nahvî, Katrü'n-nedâ ve bellü's-sadâ (thk. Muhammed Muhyiddin Abdülhamîd), Beyrut 2004, s. 124. Ayrıca bk. a. mlf. Şǚûrü'z-žeheb fì marifeti kelâmi'lArab (thk. Muhammed Muhyiddin Abdülhamîd), Beyrut 1988, s. 145; a. mlf. , Evdabu'l-mesâlik ilâ Elfiyyeti İbn Mâlik, Beyrut 1988, I, 179-184. 
almalar1 halinde insan ya da adam cinsine delalet eder hale gelmektedirler. ${ }^{85}$

Cemî' isimlere gelen harfi tarif de bu isimlerin kapsaminda genişlemeye yol açmaktadır. Meselâ "rical” denildiğinde erkeklerden oluşan bir topluluk kastedilmektedir. Ancak bu kelime, harfi tarif aldığ takdirde kapsamı genişlemektedir ve erkek cinsini ifade eder hale gelmektedir. ${ }^{86}$

\section{b. Nekre İsimler}

İsim, biliniyor olma açısından ma'rife ve nekre olmak üzere iki kısma ayrılır. İsim için asıl olan, nekre olması; fer'î olan ise ma'rife olmasıdır. Nekre, mevcut ya da mukadder olan cins üzerine şâyi olan isimdir. Mesela "adam" denildiğinde "düşünen (konuşan) erkek" kastedilmektedir. Bu cins altına giren her fert için bu ismin kullanılması doğru olmaktadır. ${ }^{87}$ Nitekim usûlcülerin çoğunluğu, nekre ismin olumlu olduğu takdirde genel bir kapsama sahip olduğunda hemfikirdir. Olumsuz nekre isimlerse zarureten âm kabul edilmektedir. ${ }^{88}$ Meselâ "mâ etâke ahadun" denildiğinde olumsuzluk, genel bir nitelik kazanmaktadır ve hiç kimsenin gelmediği ifade edilmiş olmaktadır. ${ }^{89}$

Aynı şekilde leyse'ye benzeyen "mâ, lâ, lâte, in" harfleri, gerekli şartları taşıdıkları takdirde onun gibi olumsuzluk anlamı katmaktadırlar. Ancak buna, müfred bir kelimenin cemîyi nitelemesinin ve onun hakkında haber vermesinin mümkün olmayacağı şeklinde itiraz edilmiştir. Bu itiraza söz konusu "mâ"nın, "âm bir lafız olduğu” şeklinde cevap verilmiştir. ${ }^{90}$

\footnotetext{
Semerkandî, Mî̃ân, I, 364.

Semerkandî, Mî̃ân, I, 364-365.

87 İbn Hişâm en-Nahvî, Katr, s. 103-104. Ayrıca bk. a. mlf. , Evdah, I, 82-83.

88 Semerkandî, Mî̌âan, I, 373-375.

89 Sîbeveyhi, el-Kitâb (thk. Abdüsselam Muhammed Hârûn), Kahire 1988, I, 55.

90 İbn Hişâm en-Nahvî, Şǚûr, s. 158.
} 


\section{c. Nekrenin Başına Gelen “Küllü” Kelimesi}

$\mathrm{Bu}$ kelime, nekrenin başına geldiği takdirde genel bir kapsama sahip olmaktadır. Meselâ "Her (küllii) canlı ölümü tadacaktır." meâlindeki âyette geçen “küllï” kelimesinin genel bir anlama sahip olması, nekrenin başına gelmesinden ileri gelmektedir. ${ }^{92}$

Ayrıca söz konusu kelimenin cümle içerisinde mübtedâ olması halinde de genel bir anlama sahip olduğu kabul edilmektedir. "Hepsi (küllün) O'na boyun eğmiştir."”3 meâlindeki âyette geçen "küllün" kelimesi, buna örnek teşkil etmektedir. ${ }^{94}$

\section{Karine Olmaksızın Anlaşılamayanlar.}

Başka lafizlarla birlikte âm olduğu kabul edilen lafizlardan bazılarının anlaşılabilmesi, bunu sağlayan bir karinenin varlığına bağlanmıştır. Bunlar kendi başlarına kaldıklarında anlaşılır olmadıkları için "mübhem" olarak nitelenmişlerdir. Bu lafızların anlaşılmaları, ilişkkili olduklar1 kelimelerin bilinmesini gerektirmektedir. Bu durumda da bu kelimeler ve ilişkili oldukları, tek bir kelime gibi değerlendirilmiş

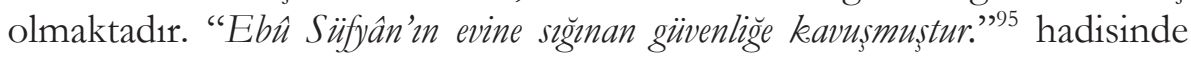
ismi mevsul, silasiyla birlikte umum ifade etmektedir. Bu yüzden $\mathrm{Hz}$. Peygamber, söz konusu hadisinde Ebû Süfyân'ın evine giren herkesin güvende olduğunu ifade etmiş olmaktadır. ${ }^{96}$

$\mathrm{Bu}$ türün en önemli örneğini ismi mevsuller ve bazı soru edatları oluşturmaktadır. İsmi mevsul, sılaya ve âide ihtiyaç duyan ma'rife kelimedir. Has ve müşterek olmak üzere iki kısımdır. Has olan ismi mevsuller; müzekker, müennes ve bunların tesniyeleri ve cemîleri için ayrı birer kelimeyle ifade edilen kelimelerdir. Müşterek olan ismi mevsullerde ise müfred-tesniye-cemî ve müzekker-müennes ayrımı

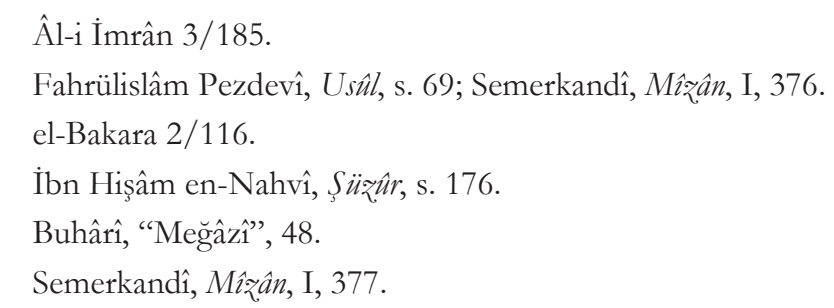


bulunmamaktadır. ${ }^{97}$ Müșterek ismi mevsullerin âm olarak nitelenmeleri, genel bir kapsama sahip olmalarından ileri gelmektedir. Buna dayalı olarak "men"in kapsamına akil sahibi varlıkların tamamı girmektedir. Aynı şekilde "mâ" akıl sahibi olmayan varlıkların tamamını kapsamaktadır."

\section{SONUÇ}

Âm lafızların kapsamına ilişkin olarak umum, husus ve vakıf olarak özetlenebilecek üç farklı görüşün ortaya çıktığı görülmektedir. Hanefîler arasındaki baskın görüş, âm lafızların genel bir kapsama sahip olduğu yönündedir ve bu açıdan Hanefîlerle Mu’tezile arasında bir görüş birliğinden bahsetmek mümkün gözükmektedir. Ancak bunu Hanefîler üzerindeki Mu’tezilî bir etki olarak görmek anakronizm olarak değerlendirilebilir. Zira Mu'tezile'nin ortaya çıkmasından yaklaşık bir asır önce gerek Ebû Hanîfe'nin gerekse Ebû Yûsufun ve Şeybânî'nin ictihadları göstermektedir ki mezhebin kurucu imâmları da âm lafizların genel bir kapsama sahip olduğunu kabul etmişlerdir. Bu konuda dikkat çekici olan bir başka husus da âm lafizlarla hususi bir mânanın kastedilmesini mümkün gören Mâtürîdîye ait görüşün Hanefîler arasında yaygınlık kazanmamış olmasıdır.

Âm lafızların kapsamına ilişkin olarak Hanefî âlimlerin görüşleri incelendiğinde konunun kelâmla olan yoğun ilişkisi de gözden kaçmamaktadır. Büyük günah işleyenlerin durumu ve bunlara uygulanacak uhrevî müeyyide, konunun kelâmî yönünü teşkil etmektedir. Bazı Hanefî âlimlerin kelâmi bir tartışma olarak büyük günah işleyenlerin durumunu âm lafizların kapsamı çerçevesinde ele almaları, bu açıdan önem taşımaktadır. Nitekim başta Cessâs olmak üzere bazı Hanefî âlimler, âm lafizların kapsamı çerçevesinde büyük günah işleyenlerin akıbetini de incelemişlerdir. Ancak konunun kelâmî yönünde Hanefîlerle Mu'tezile arasında bir görüş birliğinden bahsetmek mümkün gözükmemektedir. Hanefîlere göre büyük ya da küçük günah, kişiyi imandan çıkarmaz. Büyük günah işleyenlerin cehennemde ebedi olarak

97 İbn Hişâm en-Nahvî, Katr, s. 112-113; a. mlf., Şüzûr, s. 137-144; a. mlf., Evdah, I, 137-178. İbn Hişam en-Nahvî; mübhemi, "mânası kendi başına anlaşılamayan" olarak tanımlamıştır. bk. İbn Hişâm en-Nahvî, Şü̃ûr, s. 81.

98 Semerkandî, Mî̃âan, I, 378. 
kalmayacakları da kesin olarak bilinmektedir. Mu’tezile'ye göre ise büyük günah işleyen kişi, imandan çıkar. Ancak inanç esaslanını inkâr etmiş olmadığından dolayı "kâfır" olarak değil "fâsık" olarak nitelenir. Bu çerçevede büyük günah işleyen kişinin durumuna ilişkin olarak Hanefîlerle Mu’tezile arasında köklü bir ayrışmanın varlığı açık bir şekilde görülmektedir. Bundan daha da önemlisi, Mu'tezilî inanç sisteminin en temel esası kabul edilen söz konusu meselede Cessâs'ın Mu'tezile karşıtı görüşü açık bir şekilde temellendirmiş olmasıdır. Bu meselede Cessâs'ın Mu'tezile karşıtı bir görüşü savunmuş olması, tek başına Irak Hanefîlerinde ve özellikle Cessâs'ta Mu'tezilî etkinin varlığına yönelik tezi reddetmek için yeterli değildir. Ancak büyük günah işleyenin durumu, Mu'tezilî inanç sisteminde belirleyici bir mesele olarak görüldügünde Cessâs'ın bu konuda Mu'tezile karşıtı bir görüşü benimsemiş olmasının önemi artmaktadir.

Büyük günah işleyen kişinin durumuna ilişkin olarak Ebû Hanîfe'nin görüşü de Ehl-i sünnet akaidinin teşekkülünde belirleyici bir etkiye sahiptir. Ona göre büyük günah işleyen kişi kâfir olarak nitelenmez. Çünkü günah işlemesi, mümini küfre sokmaz. Ebû Haniffe; insanları, cennetlik ya da cehennemlik olarak değerlendirilme açısından üç kısma ayırır. Peygamberler ve cennetle müjdelenen kimseler cennetliktir. Müşrikler, cehennemliktir. Üçüncü sınıf insanlar ise Allah'ın birliğine inananlar zümresidir. $\mathrm{Bu}$ insanlar hakkında tevakkuf edilir; cennet ya da cehennem ehli oldukları söylenmez. İlahi af, umulmakla birlikte azaba çekileceklerinden de korkulur. Mürcie'nin temel görüşlerinden birisi olarak ircâ, günah işleyenlerin cennetlik veya cehennemlik olduklarını söylemeden onlar hakkındaki hükmü geciktirmek olarak anlaşılabilir. Bu durumda Ebû Hanîfe'nin büyük günah işleyenlere ilişkin görüşünde mürcî̂ bazı unsurların var olduğunu söylemek mümkündür. 


\section{KAYNAKÇA}

Abdülkahir el-Bağdâdî, Ebû Mansûr Abdülkahir b. Tâhir b. Muhammed et-Temînî, Mez̧hepler Arasindaki Farklar (trc. Ethem Ruhi Fiğlalı), Ankara 2005.

Adil Bebek, "Kebîre", DİA, XXV, 163-164.

Alâeddîn Semerkandî, Ebû Bekr Muhammed b. Ahmed b. Ebî Ahmed, Mĩ̃ânül'-usûl fì netâici'l-ukèul (nşr. M. Zekî Abdülber), Devha 1404/1984.

Aron Zysow, "Mu'tazilism and Maturidism in Hanafi Legal Theory", Studies in Islamic Law and Society (ed. Bernard Weiss), Leiden 2002.

Cessâs, Ebû Bekr Ahmed b. Alî er-Râzî, el-Fusûl fi'l-usûl (nşr. Uceyl Câsim en-Neşemî), Küveyt 1405/1985.

Debûsî, Ebû Zeyd Abdullah (Ubeydullah) b. Muhammed b. Ömer b. Îsâ, Takvîmü'l-edille (thk. Halil Meys), Beyrut 1421/2001.

Ebû Hanîfe, Nu'mân b. Sâbit b. Zûtâ b. Mâh, İmam-ı A'zam'ın Beş Eseri (trc. Mustafa Öz), İstanbul 1992.

Ebü'l-Berekât Nesefî, Hâfizüddîn Abdullāh b. Ahmed b. Mahmûd, Kesfül'-esrâr, Beyrut 1986/1406.

Ebü’l-Hasen Eş'arî, Alî b. İsmâîl b. Ebî Bişr İshâk b. Sâlim el-Basrî, Makālâtü'l-İslâmiyyinn (thk. Muhammed Muhyiddîn Abdülhamîd), Beyrut 1990.

Ebü'l-Hüseyin el-Basrî, Muhammed b. Alî b. Tayyib, el-Mu'temed (nşr. Muhammed Hamîdullah), Dimașk 1384-85/1964-65.

Ebü'l-Yüsr Pezdevî, Sadrül-İslâm Muhammed b. Muhammed b. elHüseyn b. Abdilkerîm, Ma'rifetü'l-buceci's-ser'iyye, Kahire 2003.

Emîr Pâdişâh, Muhammed Emîn b. Mahmûd el-Hüseynî el-Buhârî elMekkî, Teysîru't-tabrî, Misır 1931.

Enbârî, Ebü’l-Berekât Kemâlüddîn Abdurrahmân b. Muhammed b. Ubeydillâh, Esrârü'l-Arabiyye (thk.Muhammed Behcet el-Baytâr), Dimaşk 1357/1957.

Fahrülislâm Pezdevî, Ebü’l-Hasen Ebü'l-Usr Alî b. Muhammed b. elHüseyn b. Abdilkerîm, Usûl, baskı yeri ve tarihi yok. 
Ferhat Koca, İslam Hukuk Metodolojisinde Tabsis (Daraltıc Yorum), İstanbul 2011.

"Müşterek", $D \dot{L} A$, XXXII, 172-174.

., "Tahsis", DLA, XXXIX, 432-434.

......, "Usûlü'l-fikh (el-Fusûl fi'l-usûl) Ahmed b. Ali el-Cessâs", Marife Dini Araștirmalar Dergisi, II/3, Konya 2002, s. 337-340.

Habbâzî, Ebû Muhammed Celâleddîn Ömer b. Muhammed el-Hucendî, el-Muğnî fì usûli'l-fikh (thk. Muhammed Mazhar Beka), Mekke 1983.

İbn Hişâm en-Nahvî, Ebû Muhammed Cemâlüddîn Abdullāh b. Yûsuf b. Ahmed b. Abdillâh b. Hişâm el-Ensârî el-Misrî, Katrü'n-nedâ ve bellü's-sadâ (thk. Muhammed Muhyiddin Abdülhamîd), Beyrut 2004.

, Şüzûü'z-zeheb fî marifeti kelâmi'l-Arab (thk. Muhammed Muhyiddin Abdülhamîd), Beyrut 1988.

., Evdabu'l-mesâlik ilâ Elfiyyeti İbn Mâlik (thk. Muhammed Muhyiddin Abdülhamîd), Beyrut 1988.

İbn Kesîr, Ebü’l-Fidâ’ İmâdüddîn İsmâîl b. Şihâbiddîn Ömer b. Kesîr b. Dav' b. Kesîr el-Kaysî el-Kureşî el-Busrâvî ed-Dımaşkī eş-Şâfîi, el-Bidâye ve'n-nibâye (thk. Abdullah b. Abdülmuhsin et-Türkî), Cîze $1417 / 1997$.

İbn Manzûr, Ebü'l-Fazl Cemâlüddîn Muhammed b. Mükerrem b. Alî b. Ahmed el-Ensârî er-Rüveyfîi, Lisânü'l-'Arab, Beyrut 1414/1994.

İbnü’l-Hümâm, Kemâlüddîn Muhammed b. Abdilvâhid b. Abdilhamîd es-Sivâsî el-İskenderî, et-Tahrîr fí ilmi'l-usûl, Misır 1932.

Kādî Abdülcebbâr, Ebü’l-Hasen Kādı'l-kudât Abdülcebbâr b. Ahmed b. Abdilcebbâr el-Hemedânî, Şerbu'l-Usûli'l-hamse (trc. İlyas Çelebi), İstanbul 2013.

Lâmişî, Ebü's-Senâ, Mahmud b. Zeyd, el-Kitâb fî̀ Usûli'l-fiksh (thk. Abdülmecîd Türkî), Beyrut 1415/1995.

Madelung, Matüridiliğin Yayılması ve Türkler (trc. Arslan Gündüz), Leiden 1971. 
Mâtürîdî, Ebû Mansûr Muhammed b. Muhammed b. Mahmûd esSemerkandî, Kitâbü't-Tevbîd Tercümesi (trc. Bekir Topaloğlu), Ankara 2005.

Molla Hüsrev, Mehmed b. Ferâmurz b. Hoca Ali, Mirkātü'l-vüsûl ilâ ilmi'lusûl (trc. Haydar Sadıkoğlu), İstanbul 2012.

Serahsî, Ebû Bekr Şemsü'l-eimme Muhammed b. Ebî Sehl Ahmed, Usûlü's-Serahsî (thk. Ebü'l-Vefâ el-Efgânî), Kahire 1954.

Sîbeveyhi, Ebû Bişr (Ebû Osmân, Ebü'l-Hasen, Ebü’l-Hüseyn) Amr b. Osmân b. Kanber el-Hârisî, el-Kitâb (thk. Abdüsselam Muhammed Hârûn), Kahire 1988.

Teftâzânî, Sa'düddîn Mes'ûd b. Fahriddîn Ömer b. Burhâniddîn Abdillâh el-Herevî el-Horâsânî, et-Telvîh (nşr. Zekeriyyâ Umeyrat), Beyrut ts.

Üsmendî, Ebü'l-Feth Alâüddîn Muhammed b. Abdilhamîd b. Hüseyn esSemerkandî, Bezlü'n-nazar fîl-usul (thk. Muhammed Zekî Abdülber), Kahire 1992/1412.

Yakup Biy1koğlu, Kur'an'in Selefí Yorumu, İstanbul 2015.

Esbâb-ı Nü̃ûl ve Kur'ân'm Anlaşılması, İstanbul 2005. 